\title{
Hybrid technique for an efficient PV system through intelligent MPPT and water cooling process
}

\author{
Hussain Attia ${ }^{1}$, Khaled Hossin ${ }^{2}$ \\ ${ }^{1}$ Department of Electrical, Electronics \& Communications Engineering, American University of Ras Al Khaimah, \\ United Arab Emirates \\ ${ }^{2}$ Department of Mechanical and Industrial Engineering, American University of Ras Al Khaimah, \\ United Arab Emirates
}

\begin{tabular}{|c|c|}
\hline Article Info & ABSTRACT \\
\hline Article history: & $\begin{array}{l}\text { Solar panels have undergone several tests through research studies for the } \\
\text { purpose of improving performance to increase the resulting electrical power }\end{array}$ \\
\hline Received Feb 27, 2020 & This study considers the fact of the necessity of Maximum Power Point \\
\hline Revised Apr 26, 2020 & Tracking working conditions of the PV panels to harvest maximum electrical \\
\hline Accepted Jun 16, 2020 & $\begin{array}{l}\text { power during the weather variations. It considers also the panel temperature } \\
\text { reduction which affects positively the panel ability in terms of producing }\end{array}$ \\
\hline Keywords: & $\begin{array}{l}\text { additional electrical power. By this consideration, this study proposes a new } \\
\text { design, and simulation results with analysis of a hybrid PV system. The }\end{array}$ \\
\hline Hybrid & system is able to deliver $5 \mathrm{~kW}$, through the day hours, with less number of \\
\hline MATLAB & $\begin{array}{l}\text { two manipulating processes. The first one guarantees the Maximum Power } \\
\text { two }\end{array}$ \\
\hline MPPT & Point Tracking (MPPT) condition during day hours through an artificial \\
\hline Neural Network & Neural Network (ANN) controller. Whereas the second one focuses on \\
\hline PV matrix & reducing the panel temperature by introducing a water cooler which is \\
\hline $\begin{array}{l}\text { Simulink } \\
\text { water cooling }\end{array}$ & $\begin{array}{l}\text { designed for this purpose. Simulink software of MATLAB is used to } \\
\text { implement and evaluate the proposed system. }\end{array}$ \\
\hline
\end{tabular}

This is an open access article under the CC BY-SA license.

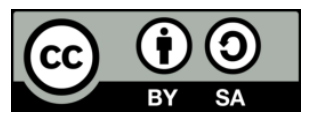

\section{Corresponding Author:}

Hussain Attia,

Department of Electrical, Electronics \& Communication Engineering

American University of Ras Al Khaimah,

Ras Al Khaimah, 10021, UAE.

Email: hattia@aurak.ac.ae

\section{INTRODUCTION}

Researchers have concentrated on the aspects of efficiency increasing of the solar photovoltaic panel [1-9]. Different parameters have been studied including the amount of delivered electrical power from the connected PV panel; the level of incident light intensity, ambient temperature, and the cleanness status of the panel surface. Also, the behavior of the PV panel in terms of instantaneous level of load power with respect to the weather condition, how this level is affected in non-linear shape by the mentioned weather parameters, and how to guarantee guaranteeing the Maximum Power Point Tracking (MPPT) working condition to have the maximum level of load power [1]. The PV panel performance enhancement through the panel temperature was investigated and analyzed in [2-6]. In [2], a water cycling process has been adopted for the panel cooling, whereas many cooling techniques have been explained in [3]. The panel efficiency has been monitored in [4] by moving the water over the panel's surface. Laboratorial experimentations have been conducted for water cooling purposes in $[5,6]$ to increase the quantity of the load power. 
The challenge of enforcing the DC-DC converters of PV systems to work at MPPT conditions has been focused by many research studies [7-10]. Fuzzy Logic Controllers (FLCs) have been proposed in [7-9] to guarantee harvesting the maximum electrical power from the solar energy. On the other side, Artificial Neural Network (ANN) have been proposed in [10] to predict the reference voltage for the aim of tracking the maximum power locations during the weather variations. The study conducted in [11], proposed an idea of an integrated photovoltaic system which has considered the advantage of inserting an algorithm of MPPT. In addition, it triggered an initial design of water cooling system to reduce the panel temperature.

The study in this paper focuses on the challenge of reducing the number of the required PV panels and maintaining the same level of delivered power from the PV system. To achieve such an aim, this paper proposes a new work based on two parallel processes. First process adopts a new MPPT controller based on a certain ANN algorithm, whereas the second process reduces the total number of the required panels by reducing panel temperature at least, $15{ }^{\circ} \mathrm{C}$ through water cooling via a mechanical solution to have a higher panels performance.

\section{THE SELECTED PV PANEL SPICIFICATIONS}

The considered PV panel module for this study is SLP060-12 of multi-crystalline type. This type is characterized by high efficiency. The specifications of the selected PV module are shown in Table 1 . The level of the harvested power reaches to $60 \mathrm{~W}$ at MPPT condition when the light intensity equals to 1000 $\mathrm{W} / \mathrm{m}^{2}$ at the room temperature, $25{ }^{\circ} \mathrm{C}$. The instantaneous level of the harvested power is nonlinear with respect to the panel voltage. Figure 1(a) shows the equivalent circuit of the solar cell, the total generated current from the solar cell, $I_{\text {out }}$, represents the summation of the diode current, $I_{D}$, the current, $I_{P}$, passing through the shunt resistor $R_{P}$, and the output current from the cell, $I_{\text {out }}$, as shown in (1)-(4)[10].

$$
\begin{aligned}
& I_{S C}=I_{D}+I_{P}+I_{\text {out }} \\
& I_{D}=I_{o}\left[e^{\frac{V_{D}}{V_{T}}}-1\right] \\
& I_{P}=\frac{V_{D}}{R_{P}} \\
& V_{\text {out }}=V_{D}-R_{S} I_{\text {out }}
\end{aligned}
$$

Figure 1 (b), (c), (d), and (e) show different instantaneous levels of output current and power at different levels of light intensity, and show different instantaneous levels of output current and power at different levels of ambient temperature, respectively.

The aim of this study is to show the positive effects of adopting the ANN based controller to harvest the maximum power from solar energy and implementing a water cooling treatment to reduce the total number of required PV panels of the proposed system via decreasing the panel temperature.

Table 1. Specifications of the Selected PV Module (SLP060-12 of Multi crystalline)

\begin{tabular}{cc}
\hline Parameter & Value \\
\hline $\mathrm{P}_{\text {mpp }}$ & $60 \mathrm{~W}$ \\
$\mathrm{~V}_{\text {out }}$ at $\mathrm{P}_{\text {mpp }}$ & $17.8 \mathrm{~V}$ \\
$\mathrm{I}_{\text {out }}$ at $\mathrm{P}_{\text {mpp }}$ & $3.37 \mathrm{~A}$ \\
$\mathrm{~V}_{\text {OC }}$ & $22 \mathrm{~V}$ \\
$\mathrm{I}_{\mathrm{SC}}$ & $3.64 \mathrm{~A}$ \\
No. of Cells and Connections & $36(3 \times 12)$ \\
Temperature Coefficient of Power & $-(0.5 \pm 0.05) \%$ per $1{ }^{\circ} \mathrm{C}$ \\
Operating Temperature & $-40{ }^{\circ} \mathrm{C}$ to $+855^{\circ} \mathrm{C}$ \\
Maximum System Voltage & $600 \mathrm{~V}$ \\
Power Tolerance & $\pm 5 \%$ \\
\hline
\end{tabular}

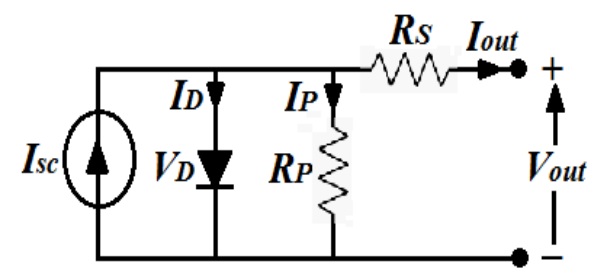

(a) 


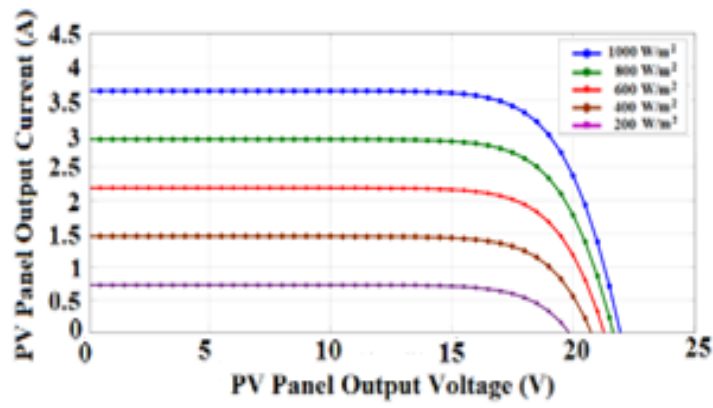

(b)

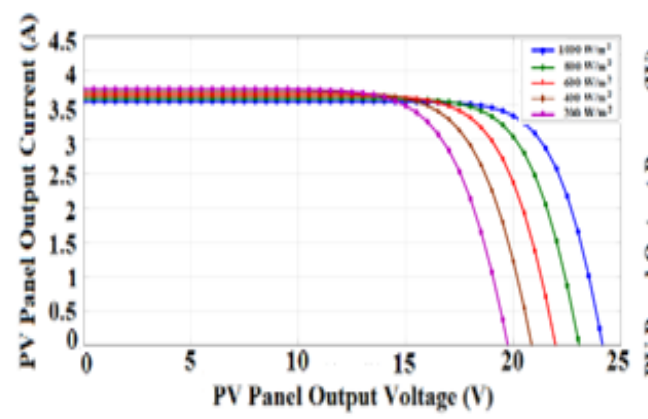

(d)

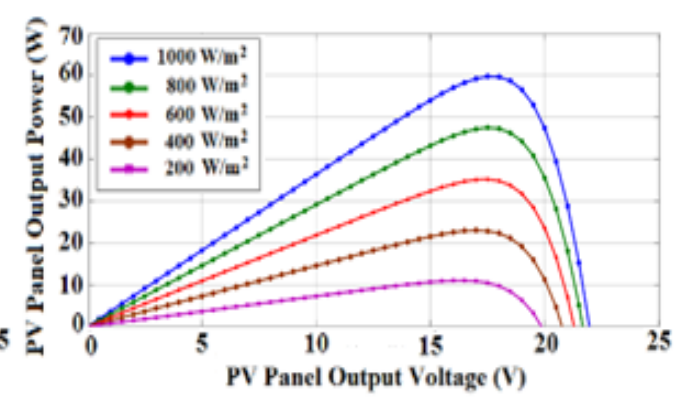

(c)

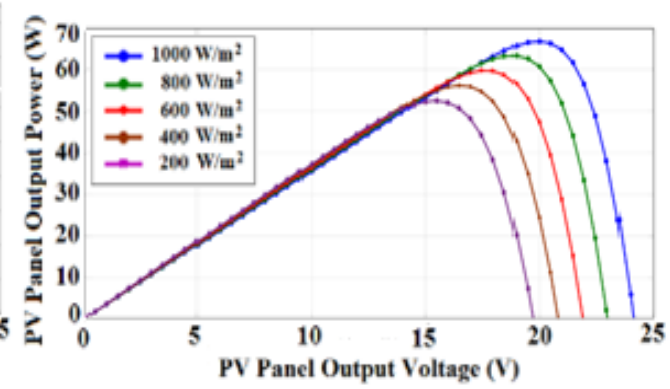

(e)

Figure 1. The selected PV panel behavior; (a) Equivalent circuit of solar cell, (b) Output current at different light intensity, (c) Output power at different light intensity, (d) Output current at different ambient temperature, and (e) Output power at different ambient temperature

\section{PHOTOVOLTAIC MATRIX DESIGN}

In order to design a suitable PV array or matrix, the total daily power required for the desired loads should be calculated. The load in this study is represented by a set of LED lamps for park lighting. The details of the lighting units and the daily working hours are shown in Table 2.

Table 2. Details of DC LED Lamps Load for Park Applications

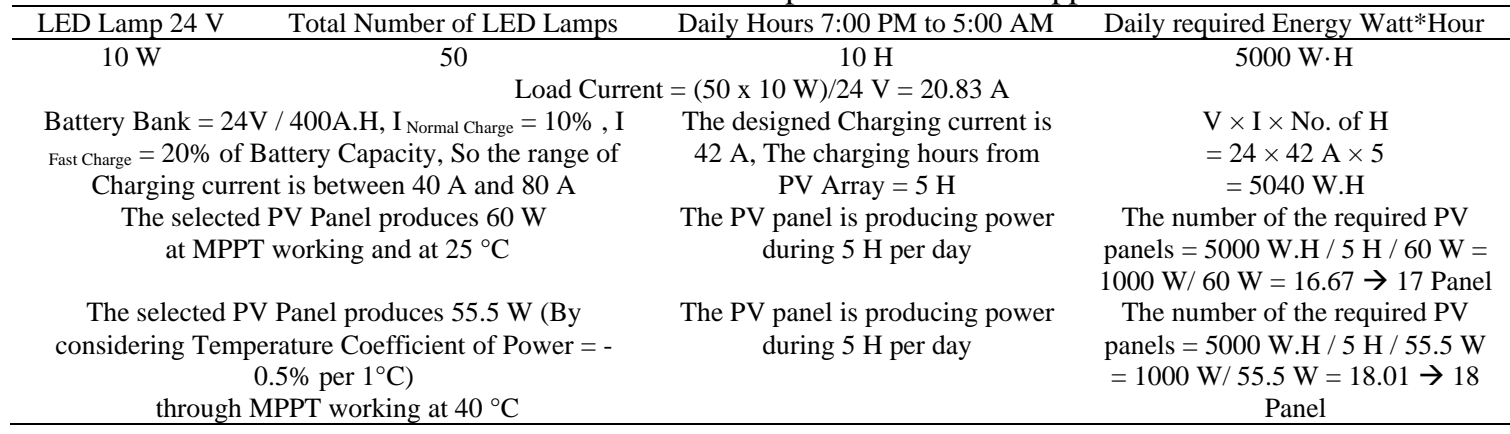

The aim of adopting the water cooling in this study is to reduce the panel temperature by 15 degrees from $40{ }^{\circ} \mathrm{C}$ to $25^{\circ} \mathrm{C}$ in order to obtain additional power of $4.5 \mathrm{~W}$ from each panel. Whereas the total amount of additional energy from the $18 \mathrm{PV}$ panels due to the water cooling during 5 hours will be $4.5 \mathrm{~W} \times 18 \times 5 \mathrm{H}$ $=405 \mathrm{~W} \cdot \mathrm{H}$. In other words, the process of water cooling can reduce the total number of the required PV panels from 18 to 17 which providing the same quantity of the harvested energy as a result of a temperature reduction from $40{ }^{\circ} \mathrm{C}$ to $25^{\circ} \mathrm{C}$. Figure 2 shows the two PV arrays connections and explains how the total panels are reduced by only adopting the water cooling process. 


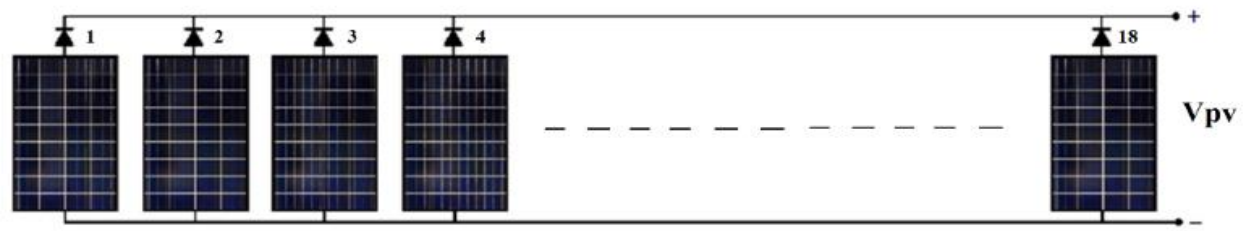

(a)

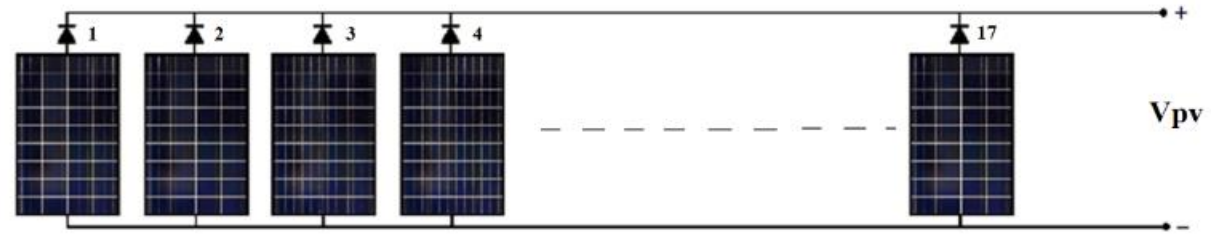

(b)

Figure 2. PV arrays connections; (a) total required panels without water cooling, (b) total required panels by adopting the water cooling treatment.

\section{PRESENTED SYSTEM DESIGN}

The design of the proposed hybrid PV system considers $5 \mathrm{~kW}$ required power from the solar PV array per 5 hours daily. This harvested energy is required to be stored in the battery bank to supply the LED lamps during the night hours. The presented design adopts a hybrid technique to guarantee the merit of the artificial neural network algorithm for MPPT aim, and the merit of panel's temperature reduction. Through the presented system, the number of the required PV panels for delivering the load power has been reduced. Figure 3 shows the main blocks and the sequence of the energy process in the hybrid PV system. The system is started by the designed array of PV panels. The panels are connected in parallel to produce higher DC current with DC link voltage of the PV panel. The link voltage is used as a power supply to the connected DC-DC converter. The adopted type of the converter is a boost converter topology.

The output voltage of the converter is regulated by the pulse width modulation (PWM) drive pulses which are controlled by the artificial neural network. The ANN algorithm works on guaranteeing the Maximum Power Point Tracking (MPPT) by predicting the instantaneous reference voltage for each instantaneous weather conditions of different light intensity values $(G)$ and ambient temperatures $(T)$.

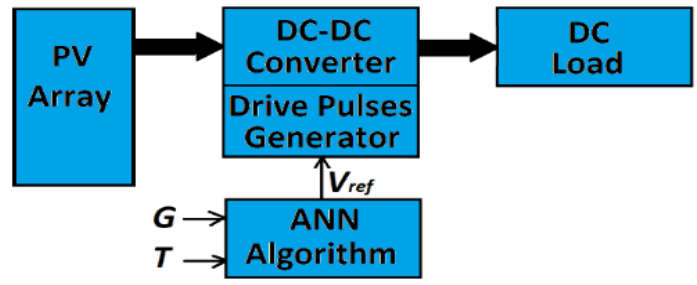

Figure 3. Main block diagram of the proposed hybrid PV system

\section{NEURAL NETWORK CONTROLLER}

The function of the designed and presented controller is producing the instantaneous value of the reference voltage. A new design of Feed-Forward Neural Network algorithm is proposed in this study to the system converter. The ANN merits of the accurate and quick response regardless the type of the controlling function led to adopt the ANN in different field problems. The algorithm is training through a machine learning process to predict the accurate solutions [10]. The learning process deals with numerical arrays of input variables and output variables. Then based on this process, the algorithm will be able to predict the numerical value of the output variable at different input variables. In this study, the algorithm is learned by the input numerical arrays of the light intensity $(G)$ and the ambient temperature $(T)$ to predict an accurate reference voltage $\left(V_{r e f}\right)$ for the MPPT function. Figure 4 shows the structure of the designed algorithm which includes one input layer of two neuron, two hidden layers of ten neuron each, and one output layer of one neuron. 
The quality of the presented Neural Network algorithm in terms of accuracy is evaluated by observing the mean square error (MSE). Low value of MSE indicates a high accuracy ANN algorithm;

$$
M S E=\frac{1}{Q} \sum_{k=1}^{Q}[t(k)-a(k)]^{2}
$$

Where the target value is indicated by $t(k)$, the predicted value of the algorithm is indicated by $a(k)$, the input vector sequence is indicated by $Q$.

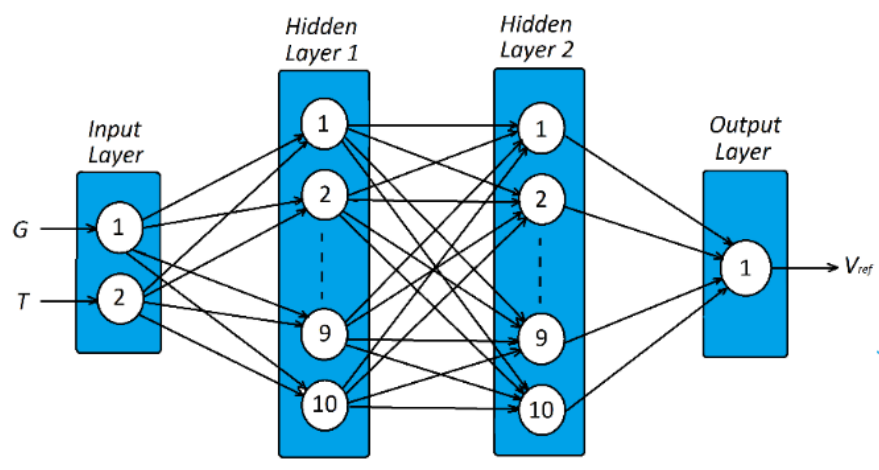

Figure 4. Proposed neural network algorithm

\section{WATER COOLING PROCESS}

Cooling of PV panels is a vital factor in the design and operation of solar cell. Integrating Photovoltaic/Thermal (PV/T) solar system is one of the most common means for the PV panels cooling to improve their overall performance. Water cooling technique is considered as one of the most effective methods among the available techniques nowadays [12].

In this study, a water-spray-based cooling system is proposed to cool the PV panels as illustrated in Figure 5. Such a system enables the possibility of using the warm water leaving from the PV panels for domestic applications. Two models are used in this work namely, heating rate model and cooling rate model. The use of these models minimizes both amounts of cooling water used and the energy required to maintain the PV panels at its desired operating temperature. The heating rate model determines the time at which the cooling of the PV panels should start while the cooling rate model determines how long it takes to cool the PV panel down to the desired operating temperature. This model is basically used to minimize the required cooling process period which in turn ensures minimum amount of water and energy needed for this purpose.

\subsection{The heating rate model}

The cooling frequency of the PV panels is determined using the heating rate model. This requires that the heating rate of the panels to be known. The heating rate of the panels can be calculated after obtaining the module temperature as a function of time. The module temperature, Tm, can be calculated using the following formula $[12,13]$ :

$$
T_{m}=T_{a m b}+\left(T_{N O C}-20\right) G / 800
$$

where $T_{a m b}$ is the ambient temperature, $T_{N O C}$ is the nominal operating cell temperature and $G$ is the irradiance in $\mathrm{W} / \mathrm{m} 2$. Equation (6) is widely used to estimate the module temperature throughout the year in a simple way $[14,15]$.

The nominal operating cell temperature, $T_{N O C}$, can be defined as a function of the ambient air temperature at the sunrise time, $T_{\text {rise }}$, as [16]:

$$
T_{\text {NOC }}=T_{\text {rise }}+20^{\circ} \mathrm{C}
$$

The heating rate, $d T_{m} / d t$, of the PV panel can be determined from the slope of the $T_{m}$-time curve by conducting linear curve fitting [12]. Knowing the PV panel heating rate as well as the maximum allowed temperature (MAT) set point, it can be directly determined when to start cooling of the PV panel as soon as the module temperature reaches the MAT. 


\subsection{The cooling rate model}

The cooling rate of the PV cells is a vital factor that significantly affects their performance. Knowing the cooling rate of the PV panel, the cooling process duration can be determined by applying the energy balance principle [17] as:

The heat energy transferred to the cooling water is equal the heat dissipated from the PV panels. In a mathematical representation, this can be written as:

$$
\dot{m}_{w} \times t \times c_{p w} \times \Delta T_{w}=m_{g} \times c_{g} \times \Delta T_{g}
$$

where $\dot{m}_{w}$ is the water mass flow rate, $m_{g}$ is the mass of glass, $c_{p w}$ is the specific heat of water, $c_{g}$ is the heat capacity of glass, $\Delta T_{w}$ is the water temperature rise, $\Delta T_{g}$ is the glass temperature drop due to water cooling, and $t$ is the time needed to cool the solar PV panel to a desired operating temperature.

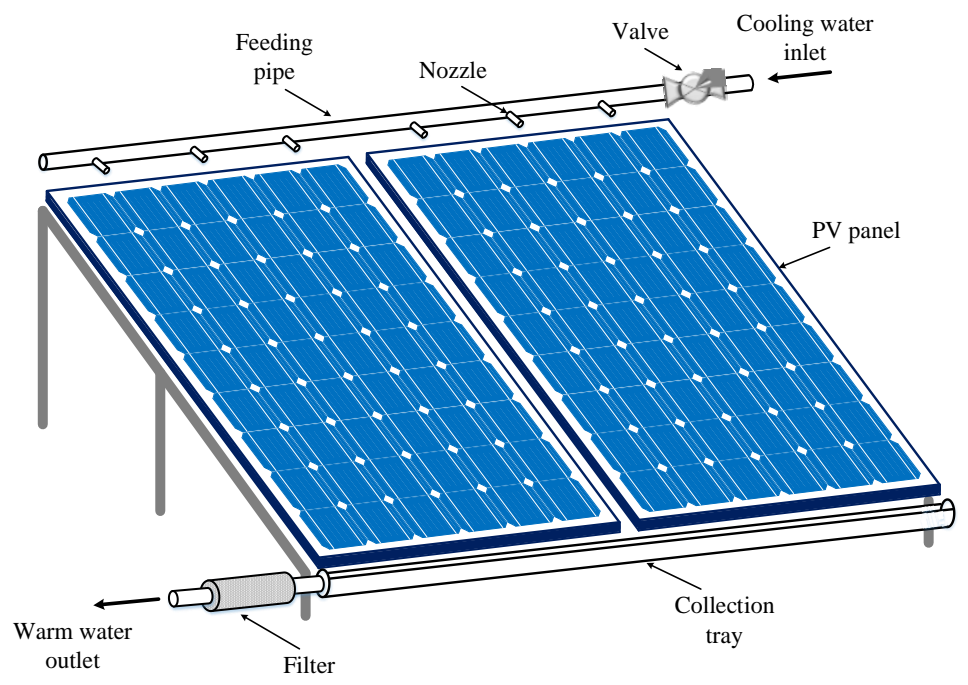

Figure 5: Schematic diagram of the PV module with the water cooling system

\section{RESULTS ANALYSIS}

MATLAB/Simulink is used in this work to simulate the proposed hybrid PV system, to assembly the simulation results for the objective of analysis, and system performance evaluation. The proposed system involves a PV array which is designed and analyzed in a previous section based on the power calculation. The system also involves a boost DC-DC converter. Table 3 shows the designed converter's parameters using the process of converter design [18-26]. The simulation results are collected for a full simulation period of 1 second which is equally divided into eight sub periods of $0.125 \mathrm{sec}$ each. The simulation is conducted in a parallel process for the two $\mathrm{PV}$ arrays $\left(17\right.$ panels at temperature of $25^{\circ} \mathrm{C}$, and 18 panels at temperature of 40 ${ }^{\circ} \mathrm{C}$ ) at the same eight levels of the following light intensity $700 \mathrm{~W} / \mathrm{m}^{2}, 750 \mathrm{~W} / \mathrm{m}^{2}, 800 \mathrm{~W} / \mathrm{m}^{2}, 850 \mathrm{~W} / \mathrm{m}^{2}, 900$ $\mathrm{W} / \mathrm{m}^{2}, 850 \mathrm{~W} / \mathrm{m}^{2}, 800 \mathrm{~W} / \mathrm{m}^{2}$, and $750 \mathrm{~W} / \mathrm{m}^{2}$.

Table 3. Boost DC-DC converter parameters

\begin{tabular}{cc}
\hline Parameter Name & Parameter Value \\
\hline Inductor & $2 \mathrm{mH}$ \\
Capacitor & $1500 \mu \mathrm{F}$ \\
Switching frequency & $15 \mathrm{kHz}$ \\
$\mathrm{P}$ - Proportional gain & 0.038 \\
I- Integral gain & 0.004 \\
\hline
\end{tabular}

The simulated structure of the designed neural network is shown in Figure 6, whereas the algorithm performance is shown in Figure 7. As demonstrated in Figure 7, the value of MSE equals to $2.7665 \times 10^{-6}$ which reflects a high accuracy performance. Figure 8 and Figure 9 show the load voltage and load power respectively for the two cases of $17 \mathrm{PV}$ panels array at $25^{\circ} \mathrm{C}$ and $18 \mathrm{PV}$ panels array at $40{ }^{\circ} \mathrm{C}$, respectively. 
Figure 8 shows the load voltage at different light intensities. This figure demonstrates approximately equal voltages with the merit of all are capable to charge the battery bank because all are greater than the $24 \mathrm{~V}$ of battery voltage. On the other side, the load power is shown in Figure 9, in which there are approximately equal power levels. This means that the positive effects of adopting ANN algorithm for MPPT function and adopting the water cooling of the PV panels lead to reduce the total number of the required PV panels.

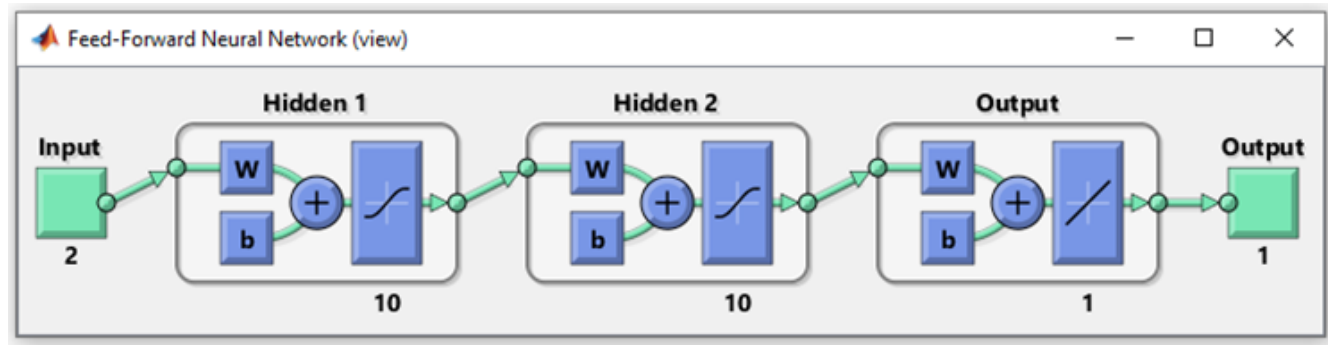

Figure 6. The simulation of the proposed ANN algorithm

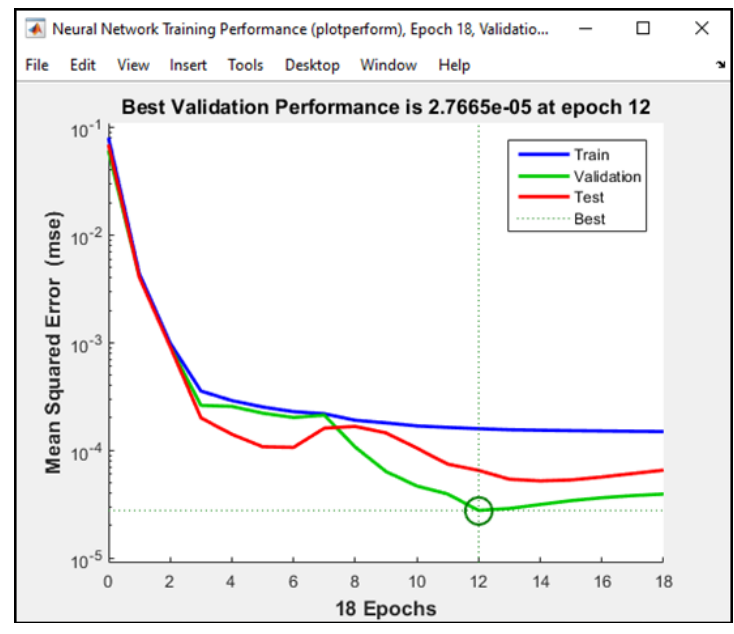

Figure 7. The performance of the simulated ANN algorithm

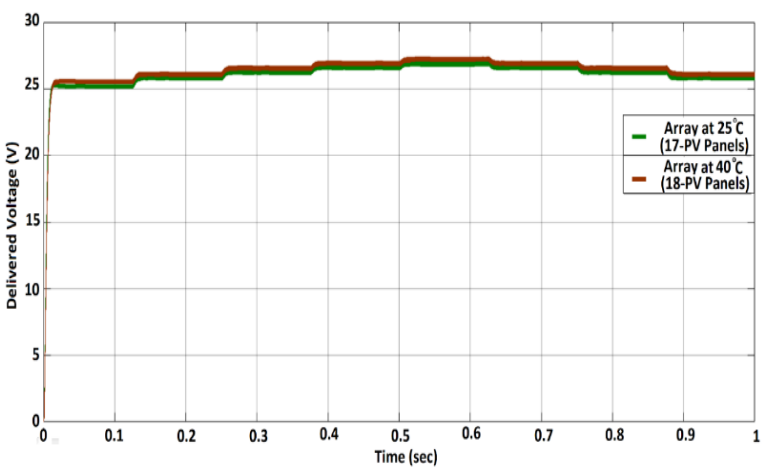

Figure 8. Simulation results of load voltage

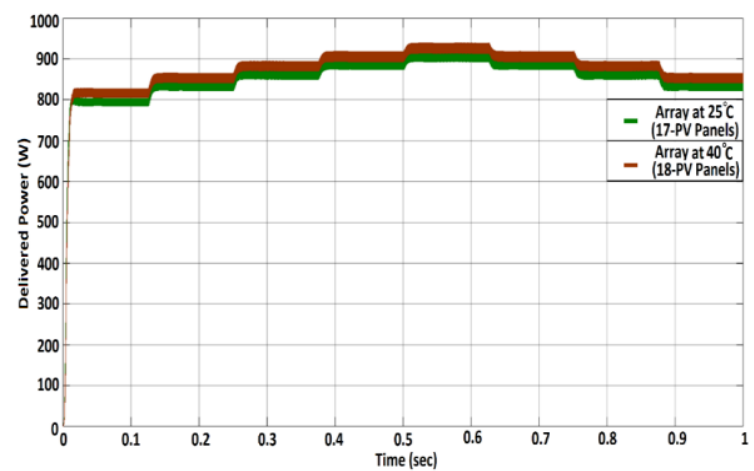

Figure 9. Simulation results of load power

\section{CONCLUSION}

A new hybrid PV system is presented in this paper for increasing the system performance and, at the same time, reducing the total number of the required PV panels. To improve the system performance, the proposed design adopts two parallel process; first process focuses on proposing a new design of an artificial neural network algorithm for the aim of guaranteeing the maximum power point tracking during all of day 
hour to harvest maximum quantity of electrical energy through the weather variation. Whereas the second process focuses on improving the performance of the PV panels by reducing the panel's temperature by water cooling treatment. The presented system considered 50 units of LED lighting of $10 \mathrm{~W}$ each as direct current appliances of the designed system. The simulation steps of the presented hybrid PV system were performed using MATLAB/Simulink. It was clearly shown the positive effects of the two parallel processes in reducing the number of the required panels with the merit of keeping the same level of the harvested energy.

\section{ACKNOWLEDGEMENTS}

The authors appreciate the financial support provided by school of engineering, American University of Ras Al Khaimah - UAE, www.aurak.ac.ae/en/school-of-engineering/

\section{REFERENCES}

[1] H. A. Attia, T. K. S. Freddy, H. S. Che, W. P. Hew, A. El Khateb, "Confined Band Variable Switching Frequency Pulse Width Modulation (CB-VSF PWM) for Single-Phase Inverter with LCL Filter," IEEE Transaction on Power Electronics, vol. 32, no. 11, pp. 8593-8605, Nov 2017.

[2] Mohd Ehtishaan, MD Rizwan Saifee, "Simulation Based Intelligent Water Cooling System for Improvement the Efficiency of Photo-Voltaic Module,” IJCSMC, Vol. 5, Issue. 7, pp. 535-544, July 2016.

[3] Filip Grubišić-Čabo, Sandro Nižetić, Tina Giuseppe Marco, "Photovoltaic Panels: a review of the Cooling Techniques," Transactions of FAMENA - Special issue 1, pp. 63-74, 2016.

[4] Matthew K. Smith, Hanny Selbak, Carl C. Wamser, Nicholas U. Day, Mathew Krieske, David J. Sailor, Todd N. Rosenstiel, "Water Cooling Method to Improve the Performance of Field-Mounted, Insulated, and Concentrating Photovoltaic Modules," Journal of Solar Energy Engineering, Vol. 136, No. 3, 2014.

[5] Saad Odeh, and Masud Behnia, "Improving Photovoltaic Module Efficiency Using Water Cooling," Heat Transfer Engineering, Vol. 30, No. 6, pp. 499-505, 2009.

[6] Saira Iqbal, Samia Afzal, Atta Ullah Mazhar, Hazeema Anjum, Anab Diyyan, "Effect of Water Cooling on the Energy Conversion Efficiency of PV Cell," American Scientific Research Journal for Engineering, Technology, and Sciences (ASRJETS), Vol. 20, No 1, pp. 122-128, 2016.

[7] Hussain Attia, "A Stand-alone Solar PV System with MPPT Based on Fuzzy Logic Control for Direct Current Portable House Applications", International Review on Modelling and Simulations, Vol. 11, No. 6, pp. 377-385, 2018.

[8] Hussain Attia, "Fuzzy Logic Controller Effectiveness Evaluation through Comparative Memberships for Photovoltaic Maximum Power Point Tracking Function," International Journal of Power Electronics and Drive Systems (IJPEDS), Vol. 9, No. 3, pp. 1147-1156, 2018.

[9] Attia Hussain, Del Ama Gonzalo Fernando, "Stand-alone PV System with MPPT Function Based on Fuzzy Logic Control for Remote Building Applications," International Journal of Power Electronics and Drive Systems (IJPEDS), Vol. 10, No. 2, pp. 842-851,2019.

[10] Hussain A. Attia, "High performance PV system based on artificial neural network MPPT with PI controller for direct current water pump applications," International Journal of Power Electronics and Drive Systems (IJPEDS), Vol. 10, No. 3, pp. 1329 1338, 2019.

[11] Hussain Attia, Khaled Hossin, "Integrated Renewable PV System through Artificial Neural Network Based MPPT and Water Cooling Treatment," International Conference on Electrical and Computing Technologies and Applications (ICECTA), Ras Al Khaimah-UAE, November 19-21, 2019.

[12] Moharram KA, Abd-Elhady MS, Kandil HA, El-Sherif H, "Enhancing the performance of photovoltaic panels by water cooling," Ain Shams Engineering Journal, Vol. 4, no. 4, pp. 869-877., 2013.

[13] Alonso Garcia MC, Balenzategui JL, "Estimation of photovoltaic module yearly temperature and performance based on nominal operation cell temperature calculation," Renewable Energy, Vol. 29, No. 12, pp. 1997-2010, 2004.

[14] Kotlay P, Wenk J, Bucher K, "Outdoor measurements of NOCT and its influence on energy collection," Proceedings of the Second World Conference on PV Solar Energy Conversion, Vienna, pp. 2334-7, 1998.

[15] Malik AQ, Salmi Jan Bin Haji Damit, "Outdoor testing of single crystal silicon solar cells," Renewable Energy, Vol. 28, No. 9, pp. 1433-45, 2003.

[16] Bharti R, Kuitche J, Tamizh-Mani G, "Nominal operating cell temperature (NOCT) effects of module size, power, load and solar spectrum," In: 2009 34th IEEE Photovoltaic Specialists Conference (PVSC), Arizona State University, USA, 7-12 June, pp.1657-62, 2009.

[17] Cengel YA, Boles MA., "Thermodynamics: an engineering approach," 5th ed. New York: McGraw-Hill Science; 2005.

[18] Norazlan Hashim, Zainal Salam, Dalina Johari, Nik Fasdi Nik Ismail, "DC-DC Boost Converter Design for Fast and Accurate MPPT Algorithms in Stand-Alone Photovoltaic System," International Journal of Power Electronics and Drive Systems (IJPEDS), Vol. 9, No. 3, pp. 1038-1050, 2018.

[19] L Navinkumar Rao, Sanjay Gairola, Sandhya Lavety, Noorul Islam, "Design of DC-DC Boost Converter with Negative Feedback Control for Constant Current Operation" International Journal of Power Electronics and Drive Systems (IJPEDS), Vol. 8, No. 4, pp. 1575-1584, 2017. 
[20] G. Seshagiri Rao, S. Raghu, N. Rajasekaran, "Design of Feedback Controller for Boost Converter Using Optimization Technique," International Journal of Power Electronics and Drive Systems (IJPEDS), Vol. 3, No. 1, pp. 117-128, 2013.

[21] Basem E. Elnaghi, Mohamed E. Dessouki, M.N.Abd-Alwahab,Elwy E. Elkholy, "Development and implementation of two-stage boost converter for single-phase inverter without transformer for PV systems," International Journal of Electrical and Computer Engineering (IJECE), Vol.10, No.1, pp. 660-669, 2020.

[22] R.Palanisamy, C.S.Boopathi, K.Selvakumar, K.Vijayakumar, "Switching pulse generation for DC-DC boost converter using Xilinx-ISE with FPGA processor," International Journal of Electrical and Computer Engineering (IJECE), Vol.10, No.2, April2020, pp. 1722 1727.

[23] S.Daison Stallon, K.Vinoth Kumar, S.Suresh Kumar, "High Efficient Module of Boost Converter in PV Module," International Journal of Electrical and Computer Engineering (IJECE), Vol. 2, No. 6, , pp. 758-781, 2012.

[24] R. Palanisamy, K. Vijayakumar, V. Venkatachalam, R. Mano Narayanan, D. Saravanakumar, K. Saravanan, "Simulation of various DC-DC converters for photovoltaic system," International Journal of Electrical and Computer Engineering (IJECE), Vol. 9, No. 2, pp. 917-925, 2019.

[25] J. Santhosh Reddy, Santosh Sonar, "Closed Loop Control of Multilevel Dc-Dc Boost Converter," International Journal of Engineering and Advanced Technology (IJEAT), Vol. 9, No. 2, pp. 4512-4518, 2019.

[26] V.C. Kotak, Preti Tyagi, "DC To DC Converter in Maximum Power Point Tracker," International Journal of Advanced Research in Electrical, Electronics and Instrumentation Engineering, Vol. 2, Issue 12, Dec. 2013, pp. $6115 \sim 6125$.

\section{BIBLIOGRAPHY OF AUTHORS}

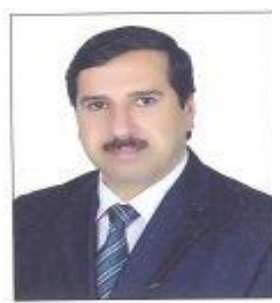

Hussain Attia earned his Ph.D. degree in Power Electronics from the University of Malaya, Kuala Lumpur, in 2019. Hussain serves as a reviewer to IEEE Transactions on Power Electronics, Journal of Emerging and Selected Topics in Power Electronics, IET Power Electronics, and IEEE conferences. Hussain's research interests: Power Electronics Systems, AC \& DC Speed Control Drives, PWM Inverters (single phase \& three phases), Harmonics reduction techniques, and Maximum Power Point Tracking techniques.

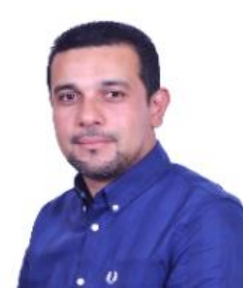

Dr. Khaled Hossin is an assistant professor in Mechanical Engineering at the American University of Ras Al Khaimah, UAE. Dr. Hossin received a PhD in Mechanical Engineering from Northumbria University, UK. He is a member of editorial board and reviewer for numerous International Scientific Journals as well as a member at several national and international scientific and professional bodies.

His research area of interest includes Organic Rankine Cycles, Solar Thermal Systems, Biomass Energy, Thermal Power Plants, and Energy Systems Optimization. 